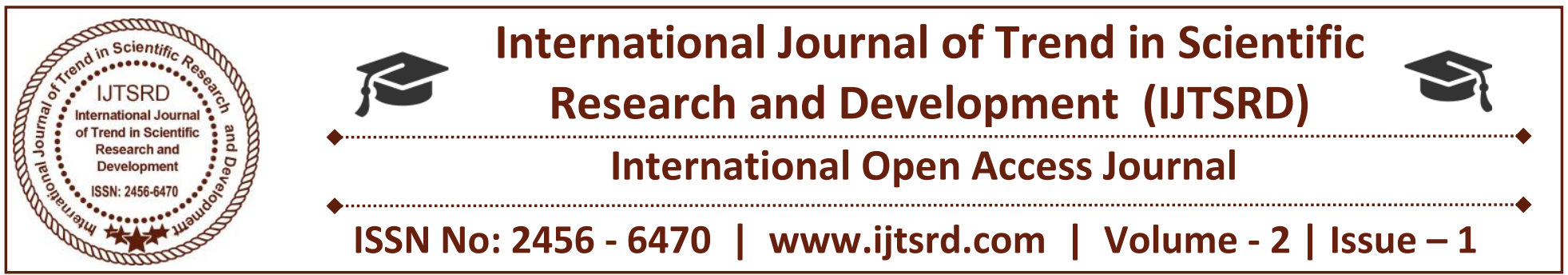

\title{
Youth Unemployment and Poverty in Nigeria: Effective Social Protection as a Panacea
}

\author{
Mu'azu Abdullahi Ishaq \\ Department of Sociology, Federal University \\ Dutse, PMB 7156, Jigawa State, Nigeria
}

Aminu Abdullahi

Department of Sociology, Federal University Dutse,

PMB 7156, Jigawa State, Nigeria

\author{
Sulaiman Isyaku Muhammad \\ Department of Sociology, Federal University Dutse, \\ PMB 7156, Jigawa State, Nigeria \\ Jamilu Abdulahmid Bello \\ RMK, College of Arts, Sciences and Remedial \\ Studies, Tudun Wada Kano, Kano State
}

\section{ABSTRACT}

This paper examines the problem of youth unemployment and poverty in Nigeria, with a view of highlighting the need for effective and sustainable social protection strategy in the country. Majority of Nigerians are engulfed in the ocean of poverty. The Nigerian government seem to have shown lighter effort in its contractual obligation to provide socioeconomic security to its citizens. There is drastic collapse of social security, increase in unemployment rate and consequently high rate of poverty. Youth are very important stakeholders in any society; they are regarded not only as useful resources in nationbuilding but also the backbone of any societal development. The primary objective of this paper is to identify the dual problem of poverty and unemployment especially among the youths as the major disease that crippled the attempt by Nigeria to achieve sustainable development and at the same time ascertain the need for the formulation and implementation of effective and sustainable social protection strategy as a means of tackling the ever increasing rate of unemployment and poverty in Nigeria. The paper recommended that, for Nigeria to tackle unemployment and poverty problem, the priority of the people shall be identified, corruption must be eliminated and informal sectors, such as agriculture, shall be incorporated into the national economic priority, not public sector or oil alone.
Keywords: Youth, Unemployment, Poverty, Social protection, panacea, Nigeria

\section{Introduction}

The issue of articulating and implementing policies that are aimed at alleviating or eradicating poverty and unemployment had proved to be the most difficult challenge facing any country in the developing world Nigeria inclusive, where on the average, majority of the population are considered to be poor. And these challenges had adversely affected sustainable development in many of the country. However, in the last decade, social protection has emerged as a policy framework employed to address poverty and vulnerability in developing countries. (Barrientos, 2010)

A range of factors signal the rise to prominence of social protection. International development organizations, especially agencies within the United Nations family, have adopted and adapted social protection strategies and policies. A growing number of national governments in the developing world are developing and adopting national social protection strategies within their poverty reduction planning. There is a rapid escalation in the number and coverage of social protection policies and programmes being implemented in developing 
countries. There is also rising interest in social protection among development researchers, development research institutes, and higher education.

In the 1990s, social protection underwent an important transformation, especially in the context of developing countries. Against a background of economic crises, structural adjustment and globalization, social protection in developing countries has increasingly come to describe a policy framework for addressing poverty, unemployment and vulnerability. It can be defined as "public actions taken in response to levels of vulnerability, risk, and deprivation which are deemed socially unacceptable within a given polity or society", Conway et al. (2000:2). Cited in (Barrientos, 2010)

Even though there is no universally accepted definition of poverty due to its multi dimensional nature, yet it is commonly defined as a situation of low income or low consumption. In another definition poverty can be regarded as a situation in which individuals are unable to meet the basic necessities of life such as food, clothing, shelter, education, security and health. However, when talking about poverty, organizations often use different definitions. According to the World Bank organization; Poverty is defined relative to the standards of living in a society at a specific time. People live in poverty when they are denied an income sufficient for their material needs and when these circumstances exclude them from taking part in activities which are an accepted part of daily life in the society. (IBDR 2009)

What the World Bank organization is saying in essence is that poverty cannot be defined separately without taking the economic situation into keen consideration. When individuals or a given greater number of citizens in a country cannot purchase their insatiable needs (both material and non-material), then they can be referred to as wallowing in an abject poverty. This, according to the world bank organization, is as a result of the denial of their income as a result of the fact that the principles of "PAYE"e i.e. pay as you earn, is not always applicable to every society; therefore, individuals tend to pay higher taxes than they earn, and this leaves the bourgeoisies richer while the peasants and proletariat keep on getting poorer.

However, the House of Commons Scottish affairs committee: (cited in Duru 2013) provide a more comprehensive definition of poverty, when it posits that "There are basically three current definitions of poverty in common usage", these include: absolute poverty, relative poverty and social exclusion. They not only mentioned the above listed, but also went ahead to elucidate on them. Absolute poverty is defined as the lack of sufficient resources with which to keep the body and soul together. Relative poverty on the other hand, defines income or resources in relation to the average. It is concerned with the absence of the material needs to participate fully in accepted daily life. Social exclusion as the third division of poverty is a new term often used by the government. According to their definition, social exclusion can be defined as ...... a shorthand label for what can happen when individuals or areas suffer from a combination of linked problems such as unemployment, poor skills, low incomes, poor housing, high crime environments, bad health and family breakdown.

Poverty therefore is a condition of being poor; deficiency; inadequacy, or scarcity. Poverty is a condition of having insufficient resources or income. In its most extreme form, poverty is a lack of basic human needs, such as adequate and nutritious food, clothing, housing and health services. Poverty also relates to other things such as poverty of ideas or information. Poverty in the most common usage can be defined as the insufficiency of means relative to human needs (Akwara et al 2013). However, poverty does not affect only the individual, but classes of people, whole societies and nations as well. In Nigeria, the sub-groups among the poor include the unemployed, those with low level of education and female - headed households (NBS, 2009).

The prevalence of poverty especially among the youth in Nigeria is mostly attributed to the menace of unemployment which has become a major problem bedevilling the lives of Nigerian youth causing frustration, dejection and dependency on family members and friends, who also have their own problems to contend with. The high rate of unemployment among the youths in Nigeria has contributed to the high rate of poverty and insecurity in the country. (Ifeoma 2013)

However, the phenomenon of Unemployment can be simply described as the condition of people who are without jobs. The International Labour Organization ILO (2007) defines the unemployed as numbers of the economically active population who are without work, but available for and seeking work, including 
people who have lost their jobs and those who have voluntarily left work (World Bank, 1998). According to Adebayo (1999) unemployment exists when the labour force wish to work but cannot get jobs. Various forms of unemployment have been identified and elaborated upon by scholars. These include seasonal, frictional, cyclical and structural employment (Adebayo, 1999; Damachi, 2001).

Youth unemployment is becoming an increasingly troublesome issue in many parts of the world. In Nigeria, it has become one of the most serious socioeconomic problems confronting the country. The magnitude of this can be appreciated if accurate statistics could be obtained from the Federal Bureau of Statistics on the number of unemployed youths roaming the streets of Nigerian cities. However, Awogbenle and Iwuamadi (2010) observed from the excerpts of statistics obtained from the National Manpower Board and Federal Bureau of Statistics showed that Nigeria has a youth population of eighty (80) million representing 60 percent of the total population of the country. Sixty four (64) million of them are unemployed while one million six hundred thousand (1.6 million) are underemployed.

Unemployment is worldwide economic problem, causing poverty and lack. In recent times, there have been notable adverse social, economic and political developments in Nigeria, a consequence of youth unemployment and underemployment, particularly exemplified by increasing militancy, violent crimes, kidnapping, restiveness and political instability. The Nigerian situation is further compounded by the recent global financial crisis that has crippled businesses and the prospect of securing jobs for young people.

This paper therefore looks at the problems of poverty and unemployment in the country and the attendant challenges they pose, and suggests that there is the need for a paradigm shift in the outlook of our leaders; a review of some of our national policies; with a view to highlight the importance of developing an effective and sustained social protection policies which is seen by many today as an integral component of any strategic effort to tackle or at least reduce the incidence and severity of unemployment and poverty in the country.

\section{Conceptual definition of terms}

\section{Youth:}

Youth in this context can be seen as young men and women who are no longer children, but not yet adults. Others have gone ahead to give a definitive age bracket to youths as those within the age range of 1530 years. In fact, in some cultures in Nigeria it may not be out of place to see people (especially men) of even 40-45 years of age claiming youth membership. Hence, the concept of youth is a relative one: a person is a youth if he or she believes so.

\section{Social protection:}

For the purposes of this paper, social protection is taken to refer to:' the public actions taken in response to levels of vulnerability, risk and deprivation which are deemed socially unacceptable within a given polity or society.' Thus Social protection deals with both the absolute deprivation and vulnerabilities of the poorest, and also with the need of the currently non-poor for security in the face of shocks and lifecycle events. The 'public' character of this response may be governmental or non-governmental, or may involve a combination of institutions from both sectors.

\section{Unemployment:}

In this context refers to a situation where an individual who is able and willing to work cannot find jobs. However, The International Labour Organization (ILO) defines the unemployed as members of the economically active population who are without work but available for and seeking work, including people who have lost their jobs or who have voluntarily left work (IBRD, 2009).

\section{Conceptual and Theoretical Discourse on Unemployment and Poverty}

One of the major challenges to social theorists and human development analysts is to sufficiently explain and find sustainable solution to the problem of poverty in the society. Poverty is generally seen to exist as a direct consequence of economic growth and advancement of the society. Several reasons are adduced by scholars in social sciences to explain the cause(s), prevalence and or effects of poverty on the individual and society.

The classical economists, including their liberal offshoot, perceive of poverty as the natural outcome of the free market system or principles which ideally provides relatively equal opportunities for every member of the society to provide his or her needs 
based on acquired capacity and capability. As individuals in the society possess different abilities, those with higher capacities naturally enjoy advantage in terms of access to resources which invariably creates wealth. They entertain the belief that the decision to be poor or not is a matter of personal choice, hence the state should refrain from intervening to mitigate the perceived negative effects or fall outs of the market on the individual or vulnerable groups.

The Fabian alternative provides a rather moderate alternative approach to dealing with the social policy problem of poverty in a free market environment by advocating the need for state intervention to mitigate the adversities of the market on the society, particularly the inequalities it wittingly or unwittingly produces. This position is currently being advocated and actively promoted by neo-liberal economic scholars and institutions to rescue not only the disadvantaged members of the society, but also the machinery of the free market, i.e. banks and corporations in distress.

However, to the radical scholars epitomized by Marx, Engels, Lenin and Dependency scholars such as Claude Ake, Gunder Frank and Walter Rodney, poverty exists in the society as the direct consequence of the expropriation of the surplus value (of the product of labour by workers and the peasantry) by the capitalist class. According to this perspective, the exploitation of the surplus value in an unequal exchange for a pittance of wage generates dependencies and invariably pauperization of the working people who are increasingly unable to meet their needs, and therefore become poor.

\section{Social protection: Towards a conceptual framework}

This section reviews the global context for social protection and highlights the reasons for the enhanced interest in the issue in the international development community. This involves addressing the diversity of definitions of and approach to social protection which are adopted by international development agencies as they develop policy in this field.

The first issue that needs to be addressed is clarification on some terms that are related to social protection, they include, Social security which is the most long-established and primarily associated with the comprehensive and sophisticated social insurance and social assistance machinery of the developed world. As such, it is seen by some as inappropriate to be discussed in much of the developing world, where higher levels of absolute poverty, combined with financially and institutionally weak states, pose a set of fundamentally different challenges.

The more recent terminology of safety nets (or sometimes more specifically social safety nets) is by contrast associated primarily with developing countries. These terms imply a more limited range of interventions - notably targeted social assistance (often now administered through social funds) which have often been originally conceived as shortterm, compensatory measures during structural adjustment or other national crises.

In the work of the International Labour Organization (ILO), social protection is associated with a range of public institutions, norms and programmes aimed at protecting workers and their households from contingencies threatening basic living standards. Broadly, these can be grouped under three main headings: social insurance, social assistance and labour market regulation. Social insurance consists of programmes providing protection against life-course contingencies such as maternity and old age, or workrelated contingencies such as unemployment or sickness. Social assistance provides support for those in poverty. Normally, social insurance is financed from contributions by workers and their employers, whereas social assistance is tax-financed. Finally, labour and employment standards ensure basic standards at work, and extend rights to organization and voice. These institutions have been fully established in developed countries, but in developing countries their development has been uneven.

The field of social protection thus encompasses many different areas and traditions of policy response. Many of these are highly technical and specialised in character (such as insurance systems, pension reform, welfare transfers, or public employment schemes). Definitions that seek to locate social protection within a broad context can go further to include famine relief, or even in some cases most activities that relate to public policy to support the well being of citizens and reduce poverty and unemployment.

The increasing importance attached to social protection issues within debates upon poverty reduction can be illustrated by comparing the two 'decennial' World Bank World Development Reports (1990 and 2000) which deal with the theme of 
poverty. WDR 90 included the theme of 'safety nets' as part of the 'three legged' poverty reduction strategy (human development and labour intensive growth constituting the other two legs). The inclusion of this theme was a landmark in re-focusing attention on the social protection role of the state in the aftermath of the neo-liberal consensus of the 1980s. Much of the debate during the 1990s was critical of the 'safety net' formulation, however, which implied a perception of the poorest as passive recipients of transfers rather than as active agents. Nonetheless, WDR 90 still represented an important watershed, bringing social protection issues back into the mainstream of the debate on international development.

In the 1990s, social protection underwent an important transformation, especially in the context of developing countries. Against a background of economic crises, structural adjustment and globalization, social protection in developing countries has increasingly come to describe a policy framework for addressing poverty and vulnerability. It can be defined as "public actions taken in response to levels of vulnerability, risk, and deprivation which are deemed socially unacceptable within a given polity or society" (Conway et al. 2000:2).

\section{Causes of Unemployment and poverty in Nigeria}

Youth's unemployment in Nigeria is a consequence of several factors. One major factor is that of population growth. Nigeria has continued to experience high rate of population growth. This increasing population growth has produced an overwhelming increase in the youth population thereby resulting in an increase in the size of the working age population. Related to the rapid population growth is the massive rural-urban migration by the youth. According to the United Nations (UN) Report (1999), cited in Ifeoma (2013) the high degree of geographical mobility of youth in Africa is in form of rural to urban which has been influencing youth unemployment. In Nigeria, youth migrate to the cities more than other migrants and in the cities, job opportunities are very limited. Thus, the rate of urbanization of the youth has continued to create unemployment.

According to Adefolalu (1992), poverty is caused by what may be called "exogenous forces" or forces outside an individual's control such as over population, high standard of living, high cost of living, inadequate education, unemployment and environmental degradation; and is also caused by "endogenous forces" or forces that operate within the victims as exemplified by individual responsibility and welfare dependency, and are thus self-created.

According to Shehu Sani (2012:14) in an article titled "poverty alleviation programme is a mirage", which appeared in Newswatch magazine on April 23, 2012 "the poverty level in the northern part of Nigeria (and by implication Nigeria in general) is as a result of a number of factors. The national factor has to do with the fact that we are operating a neo-colonialist capitalist economic system that institutionalizes the existence of class and also glorifies the widening gap between the rich and the poor". He sees a common man in the north as a victim who is a hostage of an insensitive government at the centre; insensitive government at the state level and insensitive government at the local level. He is of the opinion that the northern man is also being chained by cultural and religious factors that make it impossible for him to free himself from such bondage and poverty. In the northern part of Nigeria poverty is institutionalized and could be located from the fatalistic concept that wealth and poverty comes from God, and that the oppressed class should accept their oppressed status and pay allegiance and respect to the oppressor class.

In his own attempt to identify the factors behind youth unemployment and its negative outcome, the former Governor of the Central Bank of Nigeria Mallam Sunusi Lamido Sunusi maintained that unemployment is generally caused by improper orientation of the youths, absence of policy on social welfare, societal attitude towards vocational and technical education, and inadequate teaching facilities. These have manifested in the alarming rate of armed robberies in the south-west region; militancy and arson in the south-south region; terrorism in the north-west, northcentral and north- east regions; and in kidnapping in the south-east region. All these have impacts on the security situation in the country, and on business and investments; socio-political processes and governance. They for instance raise the cost of governance. The unemployed must find a means of livelihood and this they do by engaging in crimes and making themselves available to the political class as thugs and assassins. Political violence, ethno-religious conflicts and terrorism rife in Nigeria today are no doubt consequences of unemployment and poverty. Lamido (2013).

He goes further to reiterate that if most of our youths are employed, there would be drastic reduction in the 
level of crime and insecurity in the country. A large number of the nation's youth are unemployed and the employed are very poorly remunerated and have large number of dependents. After taxation, their take home pay cannot take them home. The law enforcement agents are very poorly remunerated, equipped, and insufficient in number to police all nooks and corners of the country. And the educational system is dysfunctional in its curriculum and has not thought of introducing entrepreneurship development in the academic curriculum until very recently. The financial institutions cannot provide loans to young and honest school leavers to start their own businesses but would rather give loans to politicians who cannot pay back these loans when they fail elections; while the poverty eradication programs designed by the governments to eradicate poverty are cornered by the politicians and those in charge of the programs in the various regions for political patronage. These have security implications in the country.

\section{Effects of Unemployment and Poverty in Nigeria}

The scourge of poverty and unemployment has ravaged almost all nations of the world in different dimensions and shades. But in Nigeria, as Akande and Okuwa (2009) pointed out, the unemployment challenge is captured by the growing number of unemployed youths roaming the streets all over the country. It is seen in the informal sector of the economy as under-employment; declining real wages; reduced incentives; reduced private investment in all sectors of the nation's economy; and a reduction in the quality of education and training given to the citizens in our educational institutions across the country. Poverty and rising crime wave are consequences of this phenomenon. In other words, unemployment in Nigeria carries with it a number of attendant social, economic, political and psychological and security challenges.

Adejumola and Tayo-Olajubulu (2009) cited in Ifeoma (2013) contended that unemployment has been identified as one of the major causes of social vices, including armed robbery, destitution, prostitution, political thuggery, kidnapping and many more. Musari (2009) corroborated this statement by saying that about 4.5 million enter the labour market every year without any hope of getting employment for life sustenance. The precarious situation has left the youths in a vicious cycle of poverty that daily erodes their self-confidence and bright future.
Another negative effect of the problem of unemployment and poverty especially among the youth has to do with the fact that it leads them to be involved in some activities that would disrupt social order in the society. This is evident on a statement made on the 14th of January 2010, by the former inspector of police Mr. Mike Okiro when he identified; marginalization, unemployment, youth exuberance and above all poverty as a major attribute of youth restiveness in the country. Okiro said this in a lecture which was titled "youth restiveness and electoral process in Nigeria".

According to Okafor (2011) unemployment in Nigeria are with attendant social, economic, political and psychological consequences. One of its social consequences on the Nigerian youths is the high level of youth unemployment. A phenomenon which encourages the development of street youths and urban urchins ("area boys") that grows up in a culture that encourages criminal behaviour. Unemployment has also contributed to increasing feminization of poverty among young women, which has encouraged prostitution as a means of survival and leads to trafficking of young women across international borders with transnational security implications.

Another statement by Nwagu (2014) corroborated the above statement when he argued that the consequences of rapid growth of youth unemployment and underemployment are naturally grave, and these are manifested in the ever growing pockets of conflicts, youth restiveness and militancy (Niger Delta youths; Movement for Actualization of Sovereign State of Biafra, Oduduwa People's Congress; Boko Haram scourge, etc.), participation in 'flourishing' organized criminal activities like kidnapping, armed robbery, political thuggery, abduction, drug abuse, vandalization of oil pipelines and national power holding installations, and other criminal activities and/or delinquent behaviour remains the only option for the idle employable youths. With the growing rate of unemployment and underemployment of the youths, Nigeria has suffered enormous loss in terms of growth and development opportunities which would have engaged their wasteful human capital. The youth employment crisis has contributed quite substantially to the high poverty incidence estimated at $54.7 \%$ of the population or 70 million. 


\section{Social protection as a remedy}

Social protection has long been a domestic concern of wealthy developed nations, which have developed sophisticated institutional arrangements in order to protect against their citizens risk and provide assistance to the destitute. Social protection has however been largely neglected, ignored or addressed only with inappropriate tools and poor political will, in the majority of poor under developed or developing countries including Nigeria where emphasis has been placed instead upon the primacy of economic growth.

In the work of the International Labour Organization (ILO), cited in Barrientos (2010) social protection is associated with a range of public institutions, norms and programmes aimed at protecting workers and their households from contingencies threatening basic living standards. Broadly, these can be grouped under three main headings: social insurance, social assistance and labour market regulation. Social insurance consists of programmes providing protection against life-course contingencies such as maternity and old age, or work-related contingencies such as unemployment or sickness. Social assistance provides support for those in poverty. Normally, social insurance is financed from contributions by workers and their employers, whereas social assistance is tax-financed. Finally, labour and employment standards ensure basic standards at work, and extend rights to organization and voice. These institutions have been fully established in developed countries, but in developing countries their development has been uneven.

Therefore, in order to have an effective Social protection policy that would help tackle the menace of poverty and unemployment in Nigeria and improved the lives of the citizenry there is need to designed an appropriate action plan that would be based on those three important components of Social Protection, Namely Social Insurance, Social Assistance and Labour Market. These components can be further broken down so as to highlight their significance in providing cure to Nigerian society that is infected with the viruses of poverty and unemployment.

\section{Social Insurance}

Employment-based social insurance schemes typically provide coverage against unemployment, inability to work due to injury or ill health, and, ultimately, old age (in the form of pensions). Contributions assure a continued income stream in the event of not being able to work. Particularly with regard to pensions, this replacement income may be fixed (to ensure a minimum pension) or earnings-related.

Crop insurance; Crop insurance can provide the same risk-mitigation function for self-employed farmers that social insurance pays for wage labourers. A payment of a regular contribution protects against harvest losses due to flood, drought, fire or pests (ADB 1999c: 9).In doing so, it can encourage smallscale farmers to experiment with innovative crops or techniques, and so contribute to economic growth and diversification. The existence of crop insurance can also be a factor in persuading lenders to extend credit to farmers lacking conventional collateral (Mishra 1994).

Health insurance; The costs of medical services constitute one of the most serious threats to the economic security of poor (and not so poor) individuals and households. Medical crises are a particularly common component of auto-correlated risk: if they strike an economically active member of the household, the unexpected rise in expenditure on treatment coincides with a drop in income. These problems were exacerbated as growing economic crisis in many low income countries in the 1970s and 1980s resulted in an inability to sustain free services. Charges were introduced either de facto (as high informal charges and corruption) or de jure (as user fees). As with social insurance for unemployment and old age, both statutory and formal private health insurance schemes are almost always beyond the reach of the poor.

\section{Social Assistance}

The second component of social protection is social assistance which covers tax-financed benefits, in cash or kind, which are funded out of the state budget (national or local), without the requirement for prior contribution from the recipient. Instead, eligibility is generally (though not always) determined by some means test. Assistance is provided to certain categories considered in need of social protection the disabled, pregnant women or families with young children, for example - who cannot be reached through labour or other market instruments, and who have been unable to purchase insurance, or for whom insurance benefits will not be sufficient. More than other social protection instruments, then, social assistance instruments are associated with explicit targeting mechanisms. 
Cash Transfers and Conditional Transfers; Cash transfer and conditional transfer programs involve the direct transfer of cash to poor households. These programs are often targeted to specific groups-the elderly, children, the malnourished, pregnant women, single parents, the disabled, or the very poor. An urban program in Mozambique, for example, gives transfers to many of these groups whose households are poor; South Africa and Namibia have old-age pension systems; and South Africa also has a child support grant and a disability grant. Such programs provide significant social and economic security that if properly adopted in Nigeria would help reduce the level of poverty in the country.

Access to microfinance; Microfinance covers the provision of savings and loans services to the poor. It could also be used to more broadly encompass privately-based insurance schemes. Attempts to provide the poor with financial services in the interests of social protection and poverty reduction should learn from these multi-functional institutional arrangements.

The provision of loans can play an important social protection role, in one of two main ways:

Originally, and in many credit schemes still, it is intended that loans are extended in order to enable poor households to invest in an income-raising or income-smoothing activity: the social protection effect is indirect, achieved through promotion of better livelihoods. Or Alternatively, loans may be given in order to enable poor households to meet critical consumption needs without needing to make recourse to coping strategies (e.g. selling or mortgaging productive assets, taking out usurious informal sector loans, withdrawing children from school to earn income, or engaging in activities with a high probability of death or disability) which entail a high risk and constrain the long-term prospects of escaping poverty.

\section{Labour Market}

These involved development and implementation of effective policies that are aimed at developing the potentialities of the citizenry and creating opportunities for them to be engaged in an income generating activities that would improve their livelihoods, this include among others;-

Employment support; Given that many poor people depend to a substantial extent on meeting consumption needs through wage employment, one way of protecting their livelihoods is through targeted employment on state projects. Some countries (notably India) have for centuries used public works as a tool of social protection, particularly when there is a threat of famine. The modern form of social protection through public works owes much to the New Deal policies of the Roosevelt administration, which aimed to use public employment not only to protect living standards but, by raising incomes, to stimulate demand. The main technical issue is the appropriate level at which to set the wage. Logic and convention suggest that wages on public works should be low (often lower than the legal minimum wage) to ensure that they are self-targeting, that is, that they are only attractive to the poor.

Public Works Programs; Public works constitute an important type of safety net pro- gram for reaching the poor throughout Africa. They provide emergency relief as well as contribute to economic development. These kinds of programs transfer short-term wages or food, but if carefully designed they can also build needed assets such as schools, clinics, and water supply and irrigation networks; facilitate access to markets through the construction of roads and market stalls; and provide training and organizational capacity. In South Africa, for example, public works programs have included support for small contractors, certified training to increase opportunities for workers to enter the labour market, and capacity building for community- based organizations involved in project implementation.

\section{Conclusion and Recommendations}

In conclusion, from what had have discussed so far, it could be deduced that effective design and implementation of social protection policies can serve as an important tool through which Third World countries like Nigeria can get themselves out of the problem of poverty and unemployment which proved to be stumbling block for their development. Therefore, the following recommendations were suggested:-

That social protection policy design and development should start from the needs, realities and priorities of the groups which are intended to benefit. A range of factors contribute to the creation of policy and programme systems responsive to the needs of the poor, with issues of governance, transparency and information assuming critical importance. 
That social protection policy development in Nigeria should take into account the rich variety of institutions outside the public sector which provide social protection functions. Thus government must engage all informal, traditional and private systems so that public policy makes best use of their potential.

That more research should be carried out on the attitudes of unemployed people towards government's policies and programmes of poverty and unemployment reduction in Nigeria; to desensitize the unemployed of their aggressive tendency and alter their perceptions of reality.

That corruption must be eliminated from the entire process of designing and implementation of social protection policies in Nigeria, Consequently, it is suggested that all the laws on corruption should be strengthened and re-enforced, and all the institutions responsible for fighting corruption like Economic and Financial Crime Commission (EFCC) and Independent Corrupt Practices Commission (ICPC) should be encouraged and supported so that the implementation of Social protection policies in the country will be corruption free.

That government must ensure an adequate understanding of the various non-state institutions and practices which provide insurance and assistance to poor people; - supporting the development of local level groups which enhance the security of livelihoods of people, with particular attention to the needs of different groups (differentiated by gender, social status and age, for example). These local collectivities may include savings and credit groups, informal mutual aid and insurance groups, or religious and custom based charity system (e.g. Zakat, Sadaqah and Hubsi in Islamic oriented societies). Support to these groups will require both programmes and appropriate regulation.

\section{REFERENCE}

1) ADB (1999), 'Framework for Operations on Social Protection'. Manila July 1999.

2) Akwara A. F. et al (2013) Unemployment and Poverty: Implications for National security and good governance in Nigeria. International journal of public Administration and management Research (IJPAMR) VII, No 1

3) Awogbenle, A.C. and Iwuamadi, K.C.(2010). Youth Unemployment: Entrepreneurship Development Programme as an Intervention
Mechanism. African Journal of Business Management 4(6) $831-835$.

4) Barrientos, A. (2010) "Social Protection and Poverty", Social Policy Development Programme paper No 42. United Nation Research Institute for Social Development (UNRISD)

5) Duru S. (2013) Poverty and Youth Restiveness in Nigeria: An evaluation of the Boko Haram crisis. Unpublished thesis submitted to the Department of Political Science, Caritas University, AmorjiNike Enugu

6) Lamido, Sanusi (2013, July 23) "Unemployment Fuelling Insecurity in Nigeria” Punch Newspaper.

7) Mishra, Pramod K. (1994) 'Crop insurance and crop credit: impact of the Comprehensive Crop Insurance Scheme on cooperative credit in Gujurat.' pp. 529-568 in Journal of International Development Vol. 6 No. 5.

8) National Bureau of Statistics (NBS) (2009): Social Statistics in Nigeria. Abuja: The NBS Publication.

9) World Development Indicators, (2009). International Bank for Reconstruction and Development/ The World Bank. New York, Washington DC.

10) Okafor, E.E. (2011): "Youth Unemployment and Implications for Stability of Democracy in Nigeria", Journal of Sustainable Development in Africa Vol.13, No.1 